\title{
COLLABORATORS OF JUSTICE: COMPARATIVE LEGAL SOLUTIONS AND CROATIAN CRIMINAL PROCEDURAL LAW****
}

Summary:

\begin{abstract}
This paper analyses the procedural position of "collaborators of justice" (potential) suspects or defendants who choose to cooperate with the authorities by contributing to the detection and prosecution of other serious crimes and perpetrators, primarily by testifying before the court. The aim of the study is to provide an overview of consensual forms and measures of reward for collaborators of justice in comparative law and then to analyse the legal position of a crown witness and a person granted witness immunity, as "collaborators of justice", in Croatian criminal procedural law. The study is conducted through a comparative legal perspective and with regard to certain issues that have so far been problematised in the scientific and professional literature and in-domestic jurisprudence, and which include: the specific goal of these consensual forms and the application of the principle of proportionality, the discretion of the state attorney and judicial control, the procedural and defence rights, and, finally, victims' rights. Special attention is given to an analysis of the jurisprudence of the Supreme Court of the Republic of Croatia and its legal standards, particularly concerning certain issues of the legality of the examination of a crown witness, as well as the legality of examination of a person granted witness immunity.
\end{abstract}

Keywords: $\quad$ collaborators of justice, crown witness, witness immunity, judicial control, measures of reward

\footnotetext{
Elizabeta Ivičević Karas, PhD, Full Professor, Faculty of Law, University of Zagreb, Trg Republike Hrvatske 14, 10000 Zagreb, Republic of Croatia. E-mail address: elizabeta.ivicevic@pravo.hr. ORCID: https://orcid.org/0000-0001-5279-3709.

** Zoran Burić, PhD, Assistant Professor, Faculty of Law, University of Zagreb, Trg Republike Hrvatske 14, 10000 Zagreb, Republic of Croatia. E-mail address: zoran.buric@pravo.hr. ORCID: https://orcid.org/0000-0001-5353-8478.

*** Matko Pajčić, PhD, Assistant Professor, Faculty of Law, University of Split, Domovinskog rata 8, 21000 Split, Republic of Croatia. E-mail address: mpajcic@pravst.hr. ORCID: https://orcid.org/0000-0003-0657-1245.

**** This work has been fully supported by the Croatian Science Foundation under the project "Systematic approach to models of negotiated justice in Croatian criminal procedure" (IP-2019-04-1275).
} 


\section{INTRODUCTION}

Modern legal orders have for decades been facing the challenge of effectively detecting and prosecuting organised crime and terrorism, which pose a threat to the very foundations of modern society. The way in which legal systems respond includes a number of different consensual forms and measures of reward for "collaborators of justice" - those (potential) suspects or defendants who choose to cooperate with the authorities by contributing to the detection and prosecution of other crimes and perpetrators, primarily by testifying before the court. Although all defendants who participate in various consensual forms, explicit or tacit, and who thus contribute to faster and more efficient criminal proceedings, could be considered kinds of "collaborators of justice" lato sensu, ${ }^{1}$ the term stricto sensu means primarily persons participating as "crown witnesses" or "repentant witnesses" in criminal procedures for the most serious criminal offences, notably corruption, organised crime and terrorism. It is precisely for these criminal offences that it is the most difficult to obtain material evidence, ${ }^{2}$ and at the same time there is generally a vow of silence among the perpetrators, and therefore prosecuting authorities have special interest in recruiting members of criminal organisations to cooperate with them. This notion of collaborators of justice stricto sensu is the subject of consideration of this paper.

The history of measures of reward for collaborators of justice is not recent in the Anglo-American legal tradition, ${ }^{3}$ while in continental European countries it dates back only to the 1980s. ${ }^{4}$ Today, the use of crown witnesses and similar consensual forms is an essential tool in the fight against the most serious crimes, especially organised crime and terrorism. The complexity of the issue is reflected in a number of disputable questions that it raises which include, among others, the morality of the use of the testimony of a repentant witness, the credibility and the probative value of such testimony, the justification of the reduction or remission of punishment, as well as the question of the equality of all before the law. ${ }^{5}$ This article does not seek to address all of these and other disputable issues. Instead it aims to provide an overview of consensual forms and measures of reward intended for collaborators of justice in American law, which, in its consensual forms traditionally inspires European legislators, and in four continental European legal systems that are traditional models for the Croatian legislator and which are regularly covered by comparative legal analyses in the field of criminal procedural law: the French, Italian, German and Austrian legal systems. The central part of the paper is devoted to the Croatian system, which will be analysed through a comparative legal perspective, and with regard to certain issues that have so far been problematised in the scientific and professional literature and in domestic jurisprudence and which include: the specific goal of these consensual forms and the application of the principle of proportionality,

1 See Beernaert, M.-A., De l'irrésistible ascension des « repentis » et " collaborateurs de justice » dans le système pénal, Déviance et Société, Vol. 27, No. 1, 2003, p. 82.

2 See Pajčić, M., Ugroženi svjedoci u kaznenom postupku, Hrvatsko udruženje za kaznene znanosti i praksu, Ministarstvo unutarnjih poslova RH, Zagreb, 2006, pp. $41-42$.

3 See Damaška, M., Dokazno pravo u kaznenom postupku: oris novih tendencija, Pravni fakultet u Zagrebu, 2001., p. 77.

4 Ibid., pp. $77-80$.

5 Beernaert, op. cit. note 1, pp. $85-87$. 
the discretion of the state attorney and judicial control, the procedural and defence rights, and, finally, the victim's rights and procedural position. ${ }^{6}$

As this paper is part of a broader study devoted to models of consensual justice in Croatian criminal procedure, the focus will be on two consensual forms: a) granting the status of crown witness; and b) witness immunity. Although there are no obstacles to using other consensual forms in order to obtain information on other crimes and perpetrators (including classic plea bargaining, especially if we bear in mind that in Croatian law a judgment based on agreement of the parties is applicable to all, including the most serious criminal offences,) they will not be the focus of this study. The reason for this is, firstly, because in Croatian law only the crown witness and witness immunity are designed for this specific purpose - to uncover and prove the most serious criminal offences of organised crime, terrorism and related offences. Secondly, for these criminal offences in three European continental legal systems which are subject to comparative analysis in this paper, it is not possible to conduct classic plea bargaining, either because it is reserved for less serious to more serious criminal offences (as in France and Italy), or because the system does not allow classic plea bargaining at all (as in Austria). ${ }^{7}$

It should be pointed out that Croatian law regulates reward instruments in substantive criminal law as well. Hence, there are possibilities to mitigate the punishment according to the general provisions of the Criminal $\operatorname{Code}^{8}$ (CC) on mitigation of punishment (Articles 48-49 CC) and for remission of punishment (Article 50 CC). In addition, there are special provisions allowing for remission of punishment relating to individual offences applicable to collaborators of justice, such as, for example, those regarding the offence of terrorist association (Article 102(3) CC), giving bribes in business dealings (Article 253(3) CC), bribery (Article 294(3) CC), conspiracy to commit a criminal offence (Article 327(2) CC), and criminal association (Article 328(3) CC). These provisions will not be subject to analysis in this paper, since the focus is on consensual procedural forms.

Finally, although the issue of the legal position of collaborators of justice naturally includes the issue of their procedural and extra-procedural protection, due to the wide range of this matter, these issues will also not be discussed here.

\section{COMPARATIVE LEGAL ANALYSIS}

\subsection{AMERICAN MODEL OF COOPERATION AGREEMENTS}

The figure of crown witness first appeared in England. ${ }^{9}$ Due to the lack of systematic criminal investigation until the mid-nineteenth century, law enforcement bodies in England relied

6 Ivičević Karas, E., Consensual Justice in Croatian Criminal Procedural Law: The Need for a Systematic Approach, in "EU 2020 Lessons from the Past and Solutions for the Future, EU and Comparative Law Issues and Challenges Series (ECLIC) - ISSUE 4, University of Josip Juraj Strossmayer Faculty of Law, Osijek, 2020, pp. 408 and 429.

7 See another article in this publication: Ivičević Karas, E., Novokmet, A., Martinović, I., Judgment Based on Agreement of the Parties in Croatian Law: A Critical Analysis from the Comparative Legal Perspective.

8 Kazneni zakon, Official Gazette 125/11, 144/12, 56/15, 61/15, 101/17, 118/18, 126/19.

9 Damaška, op. cit. note 3, p. 77. 
on the testimonies of co-perpetrators (crown witnesses) who in return received various benefits. ${ }^{10}$ This model was later taken over in the United States of America under different names, ${ }^{11}$ but in contemporary law it is connected primarily to guilty pleas. In the law of the United States, there are four principal forms of guilty pleas: open plea (when the defendant pleads guilty in return for no specific promise from the prosecution), charge bargain, sentence bargain, and a binding plea which, unlike the other three forms, actually binds the court (under the Federal Rules of Criminal Procedure $11(c)(1)(C)) .{ }^{12}$ In addition to agreeing to plead guilty, it is possible to agree to cooperate with authorities in the prosecution of other defendants and crimes and therefore to conclude a "cooperation agreement". ${ }^{13}$ This allows the defendant to receive sentencing credit, though crediting assistance may be rendered even after sentencing according to the Federal Rule of Criminal Procedure 35(B). ${ }^{14}$ A reduction in the sentence is possible only upon a prosecutorial motion certifying that the defendant provided substantial assistance in the investigation or prosecution of another person. ${ }^{15}$ But, even then, the court retains ultimate sentencing discretion, ${ }^{16}$ with the exception of the mentioned binding plea.

Since, in the United States, the state attorney is not bound by the principle of legality, he or she may offer a potential repentant witness not only a more lenient legal qualification of the offence in exchange for cooperation, which often results in a significantly lower sentence through charge bargaining, ${ }^{17}$ but also immunity from prosecution. ${ }^{18}$ The mechanism of statutory immunity enables the prosecutor to get a suspect to testify under the threat of heavy penalties, as long as the prosecutor guarantees the suspect that his or her statement will not be used against him. ${ }^{19}$ It may be concluded that, besides statutory immunity, cooperation agreements are indispensable tools in the prosecution of organised crime in the United States. ${ }^{20}$

\subsection{THE LEGAL POSITION OF COLLABORATORS OF JUSTICE IN EUROPEAN CONTINENTAL LEGAL SYSTEMS}

\subsubsection{Collaborators of justice in Italian law}

In Italy, as one of the measures of penal policy, a repentant witness (pentito) or collaborator of justice (collaboratore della giustizia) was officially regulated in 1979 first for the purpose

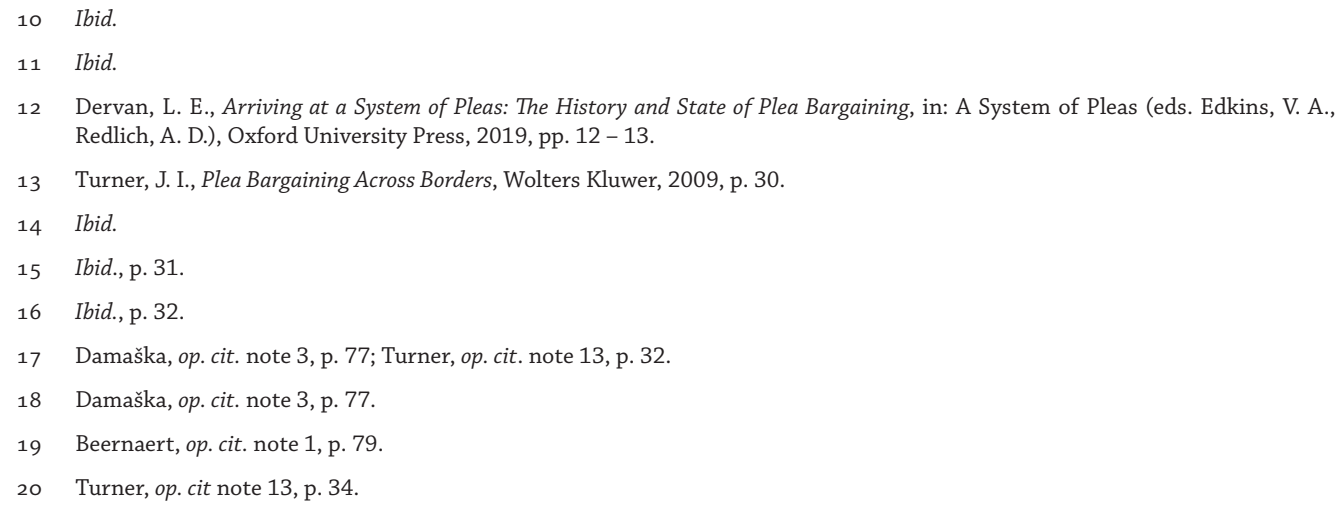


of prosecuting terrorism, ${ }^{21}$ and then was gradually expanded to other serious crimes such as kidnapping for ransom, the production of and dealing in drugs, and organised crime, ${ }^{22}$ but also to some less serious offences such as copyright infringements, cigarette smuggling or even theft. ${ }^{23}$ Today, collaboration is allowed for all offences for which arrest is envisaged. ${ }^{24}$

The mechanism is founded on the principle of legality or mandatory prosecution and operates in a way that a judge may decide not to sentence, or to impose a less severe sentence in exchange for cooperation aimed at preventing criminal offences or at providing crucial information enabling effective investigation. ${ }^{25}$ Special protection measures for pentiti are adopted in the particular administrative procedure and are used to define the status of collaborator of justice and all consequent effects, including procedural ones. ${ }^{26}$

Collaborators of justice may be granted special protection measures under certain conditions. ${ }^{27}$ The collaboration and statements made during criminal proceedings must be of "intrinsic reliability", and must be of "novelty or completeness" or "for other elements they must appear of considerable importance for the development of the investigations or for the purposes of the judgment or for the investigation activities on the structural connotations, the equipment of weapons, explosives or goods, the joint and internal or international links of criminal organizations of a mafia or terrorist-subversive type or on the objectives, purposes and operating methods of the stated organizations" ${ }^{28}$

The mechanism for rewarding cooperation with the authorities also works in the penitentiary system. At the stage of the execution of prison sentences, collaborators, and even those who have committed the serious offences of organised crime and terrorism, if they collaborate and dissociate with the criminal organisation or with terrorism, they can receive various benefits (Article 4-bis Legge sull'ordinamento penitenziario). ${ }^{29}$ On the other hand, many benefits will remain completely inaccessible, or unavailable for a longer time, for prisoners who do not cooperate with the judiciary. ${ }^{30}$

21 Beernaert, M-A., "Repentis » ou « collaborateurs de justice » : quelle légitimité dans le système pénal ? », Droit et société, No. 55, 2003/3, pp. $696-697$.

22 Tak, P. J. P., Deals with Criminals: Supergrasses, Crown Witnesses and Pentiti, European Journal of Crime, Criminal Law and Criminal Justice, Vol. 5, No. 1, 1997, p. 18. Fyfe, N., Sheptycki, J., International Trends in the Facilitation of Witness Co-operation in Organized Crime Cases, European Journal of Criminology, Vol. 3, No. 3, 2006, p. 339.

23 Beernaert, op. cit. note 21, p. 697.

24 Coppola, S., Chi è il collaboratore di giustizia, 8 Gennaio 2018, https://www.laleggepertutti.it/184662_chi-e-il-collaboratore-digiustizia Accessed 17 December 2020.

25 Tak, op. cit. note 22, p. 18; Fyfe, Sheptycki, op. cit. note 22, pp. 339 - 340.

26 Scarpino, F., Il fenomeno della collaborazione con lo stato, La figura del « collaboratore di giustizia », 7 Marzo 2016, https://www. filodiritto.com/il-fenomeno-della-collaborazione-con-lo-stato-0. Accessed 17 December 2020.

27 Decreto - legge 15 gennaio 1991, n.8, convertito, con modificazioni, dalla legge 15 marzo 1991, n.82, come modificata dalla legge 13 febbraio 2001 n. 45, Article 9. https://www1.interno.gov.it/mininterno/export/sites/default/it/assets/files/23/0479_ Decreto-Legge_15_gennaio_1991x_convertito_nella_L._15_marzo_1991x_n._82.pdf. Accessed 17 December 2020. Ibid.

29 Legge sull'ordinamento penitenziario, L. 26 luglio 1975, n. 354, il testo coordinato della Legge sull'ordinamento penitenziario aggiornata, da ultimo, dal D.L. 10 maggio 2020, n. 29. Norme sull'ordinamento penitenziario e sulla esecuzione delle misure privative e limitative della libertà, https://www.altalex.com/documents/codici-altalex/2018/11/26/legge-sull-ordinamentopenitenziario\#titolo1. Accessed 17 December 2020. 


\subsubsection{Collaborators of justice in French law}

The peculiarity of French criminal procedural law, in comparison with other European legal systems of the continental legal tradition considered in this paper, is that the principle of opportunity of criminal prosecution dominates, and not the principle of legality, i.e. of mandatory prosecution. Pursuant to Article 40(1) of the Code of Criminal Procedure (CCP), ${ }^{31}$ the public prosecutor is in principle free to decide whether or not to prosecute in a particular case. ${ }^{32}$ This, at least in theory, opens the possibility for informal agreements with suspects, even in cases of serious offences, though it is difficult to find any information on such practice. ${ }^{33}$

The status of a repentant witness (repenti) or collaborator of justice (collaborateur de justice) was officially introduced into French law in $2004 .{ }^{34}$ The main rewarding mechanism is regulated in the Criminal Code, with regard to particular offences, pertaining to terrorism, organised crime or drug trafficking, which are classified under the categories of the most serious offences (crimes) and moderately serious offences (délits). Article 132-78(1) of the Criminal Code ${ }^{35}$ (CC) stipulates that a person who has attempted to commit a specific crime or délit is, in the cases provided for by law, exempt from penalty under two conditions. Firstly, he or she must have notified the administrative or judicial authority, and, secondly, thereby made it possible to avoid the commission of the offence and, if applicable, to identify other perpetrators or accomplices. This rewarding measure is applicable only at the stage of the trial, when the court renders a judgment and when there is no particular procedure prescribed by law.

A similar rewarding measure is prescribed in Article 132-78(2) CC for a person already serving a custodial sentence for having committed a crime or délit, under the following conditions: if he or she informed the administrative or judicial authority and thereby enabled the offence to be stopped, or damage resulting from the offence to be prevented, or other perpetrators or accomplices to be identified. Under these conditions, the custodial sentence will be reduced, and the same is applicable when the person has made it possible either to avoid the commission of a related offence of the same nature as the crime or offence for which he or she was prosecuted, or to put an end to such an offence, or to prevent it from producing damage, or to identify the perpetrators or accomplices (Article 132-78(3) CC). Both these rewarding measures are applicable during the execution of a custodial sentence.

The French Criminal Code explicitly relativises the probative value of the testimony of a collaborator of justice, stipulating that no conviction may be pronounced solely on the basis of statements made by persons in the application of Article 132-78 CC (Article 132-78(4) CC).

31 Code de procédure pénale, Version en vigueur au 08 décembre 2020, https://www.legifrance.gouv.fr/codes/texte_lc/ LEGITEXT000006071154/. Accessed 6 December 2020.

32 Hamdan, S., Absprachen im französischen Strafverfahren? Nomos, 2018, p. 36.

33 Certain guarantees against possible abuses of the principle of opportunity are provided by hierarchical control within the public prosecutor's office, by the possibility for the victim to initiate public prosecution, and, in certain exceptional cases, by the possibility for the chambre de l'instruction to order prosecution. Bouloc, B., Procédure pénale, Dalloz, Paris, 2012, pp. 589 - 590. fr/jorf/id/JORFTEXT000000249995/. Accessed 7 December 2020.

35 Code pénal, Version en vigueur au 08 décembre 2020, https://www.legifrance.gouv.fr/codes/texte_lc/LEGITEXT000006070719/. Accessed 8 December 2020. 
The Code of Criminal Procedure provides another possibility for a rewarding measure. The court may grant an exceptional reduction of sentence, which may consist of up to a third of the sentence imposed, for convicted persons whose statement made to the administrative or judicial authority, before or after their conviction, has made it possible to stop or to avoid the commission of a particular offence listed in Articles 706-73, 706-73-1 and 706-74, which include crimes and offences committed by organised gangs, an offence of criminal association, as well as offences such as the crime of murder committed in an organised gang, the crime of torture and barbaric acts committed in an organised gang, crimes and offences of drug trafficking, etc. All offences belong to the categories of the most serious and moderately serious offences - crimes and délits.

\subsubsection{Collaborators of justice in German law}

German law, unlike many other national systems, does not provide the possibility for a suspect to avoid conviction by providing useful information as a crown witness or collaborator of justice (Kronzeugen) in the proceedings. Even when his or her contribution to the evidence is extremely valuable, he or she must be convicted but can expect mitigation or in some cases a waiver of the punishment.

German law provides a legal framework for cooperation with collaborators of justice in substantive law, namely Article 46b of the German Criminal Code (Strafgesetzbuch - StGB) ${ }^{36}$ According to this provision, judges can mitigate the punishment of crown witnesses or waive punishment entirely if the witness has committed a moderately serious or a serious offence and if he or she discloses knowledge of facts that contribute significantly to the investigation of a serious criminal offence from an exhaustive list of crimes under Article 100a (2) of the German Criminal Procedure Code (Strafprozeßordnung ${ }^{37}$ - StPO). ${ }^{38}$ The preconditions from the side of the potential crown witness is that he or she is the perpetrator of a criminal offence which is punishable by an increased minimum sentence of imprisonment or imprisonment for life and that he or she voluntarily discloses what he or she knows, contributing substantially to the detection of one of the offences under Article 100a (2) of the StPO which is related to his or her own offence. ${ }^{39}$ If this is the case, the court may then mitigate the penalty pursuant to Article 49 (1) of the StGB, whereby the threatened penalty of imprisonment for life is substituted by imprisonment for a term of at least 10 years.

36 Strafgesetzbuch, https://www.gesetze-im-internet.de/stgb/BJNR001270871.html. Accessed 6 December 2020. The new provisions of Article 46b came into force on 1 September 2009.

37 Strafprozeßordnung, https://www.gesetze-im-internet.de/stpo/StPO.pdf. Accessed 6 December 2020.

38 The same possibility exists if he or she discloses information through which a serious criminal offence according to Article 100a (2) StPO can be prevented.

39 Article 100a (2) of the Code of Criminal Procedure contains a list of very serious criminal offences for which telecommunication surveillance and some other special investigative orders could be applied.

The statutory requirement of a substantive connection between the offence about which the witness makes a statement and the offence of which he or she is suspected was introduced in 2013. The German legislator took the stand that offering a reduction of a sentence or exemption from punishment was not appropriate in cases where the witness makes statements about offences which are in no way related to the offences of which the witness himself is suspected. Crijns, J. H., Dubelaar, M. J., Pitcher, K. M., Collaboration with Justice in the Netherlands, Germany, Italy and Canada, Leiden University, 2017, p. 222. 
In arriving at its decision on mitigating or waiving the punishment, the court must have particular regard to the nature and scope of the disclosed facts and their relevance to the discovery or prevention of the offence, the time of disclosure, the degree of support which the offender gave to the prosecuting authorities, the severity of the offence to which the offender's disclosure relates, as well as the relationship between these circumstances and the severity of the offence committed and the degree of the offender's guilt (Article 46b (2) StGB).

It is important to mention that these provisions do not apply if the key witness only gives information after the main trial has opened. ${ }^{40}$ The German legislator also provides a mechanism for securing the truthfulness of the information of the suspect. Article 145d StGB (Misleading authorities about the commission of an offence) and Article 164 StGB (Casting false suspicion) provide penalties for giving false information and these penalties will be increased if the perpetrator provides false information in order to obtain leniency of the leniency program under Article 46b StGB.

Yet, German law does not have procedural rules regulating the above-described collaboration and neither does it have procedural rules on agreements. But this does not mean that there are no informal agreements. In practice, agreements are made between the prosecutor and the defendant before the judge applies a reduction of the sentence, but there is no formal framework for this in procedural law. Officially, it is the independent decision of court at the end of the proceedings where it decides on the possible mitigation or waiver of the sentence. Thus, the "agreement" between the prosecutor and the witness is therefore officially non-existent and therefore not binding, nor is it limited by any other formal requirements. ${ }^{41}$

\subsubsection{Collaborators of justice in Austrian law}

Before elaborating the status of collaborators of justice in Austrian law, it is important to point out that in Austrian criminal procedural law plea bargaining is not mentioned. The Supreme Court considers plea bargaining as inadmissible in any case. ${ }^{42}$ Moreover, in one decision from August 2004, the Supreme Court not only declared plea bargaining as forbidden, but it even announced that the parties involved in it may be liable to punishment. ${ }^{43}$

This stance of Austrian criminal procedural law and practice is quite original today, especially if compared to common law jurisdictions. Plea bargaining is considered to be in contradiction with the principle of ascertaining the material truth and of other essential principles of the Austrian Code of Criminal Procedure (Strafprozeßordnung - StPO), such as the principle of the authorities acting ex officio, the principle of legality, of open court, of oral proceedings,

40 The purpose of this time limitation is to make sure that the validity of the information provided by the suspect can be checked by the prosecution or court.

41 Crijns, Dubelaar, Pitcher, K.M., op. cit. note 39, p. 222.

42 Ehrbar, K., Plea Bargaining, 2018. Congress of European Criminal Bar Association. http://www.ecba.org/extdocserv/conferences/ oslo2018/PleaBargainingEhrbar.pdf. Accessed 6 December 2020.

43 OGH 24.8.2004, 11 Os 77/04 (EvBl 2005/64), cited from: Ehrbar, K., op. cit. note 42, pp. 2-3. In this decision, the Supreme Court stated: "A such agreement - which is essentially not comparable to any procedural and legally defined steps taken towards a 'diversion' - must be rejected first on the grounds of an evident violation of section 202, first and second case, of the Code of Criminal Procedure, but mainly because of its flagrant contradiction to the basic principles of Austrian criminal procedure, in particular the principle of ascertaining the material truth - which excludes any agreements of the court with (possible) criminals; it may expose the persons involved to the risk of liability under disciplinary law and criminal law (Article 302 of the Penal Code)". 
and the presumption of innocence. ${ }^{44}$ On the other hand, it must be emphasised that the cited decision of the Austrian Supreme Court originated from the time before the introduction of the crown witness regulation happened in Austria in 2011 (Articles 209a and 209b StPO ${ }^{45}$ ). It is to be expected that the attitude towards regular plea bargaining will be "softer" after the introduction of Article 209a. Considering that Austria is one of the very few countries without legally recognised plea bargaining to determine questions of guilt and sentencing, it is no wonder that the advantages and disadvantages of this form of consensual justice have been debated for some time. ${ }^{46}$

Despite the apparent aversion in Austrian doctrine and jurisprudence to classic bargaining in criminal proceedings, a certain form of settlement to obtain the testimony of witnesses in Austrian criminal law has existed since 2011. The crown witness (Kronzeuge) is regulated in the new Article 209a of the Austrian Code of Criminal Procedure (Strafprozeßordnung - StPO). ${ }^{47}$

According to Article 209a StPO, the possibility exists for the public prosecutor's office to withdraw from prosecution due to the cooperation of perpetrators of a criminal offence 1) which is subject to the jurisdiction of a regional court, 2) which is subject to the competence of the Special Prosecutor's Office for Economic Crimes and Corruption (WKStA - Wirtschafts und Korruptionsstaatsanwaltschaft) or which meets the criteria of Article 20b StPO, or 3) which falls under Articles 277, 278, 278a or 278b of the Austrian Criminal Code or which is related to such an appointment, association or organisation.

The perpetrator of that criminal offence has the right to demand proceedings in accordance with Articles 199, 200 to 203, and 205 to 209 StPO if he or she approaches the public prosecutor voluntarily, remorsefully confesses his or her contribution to the crime and reveals his or her knowledge of new facts or evidence, the knowledge of which contributes significantly to promoting the comprehensive investigation of another criminal offence that fulfills the above-mentioned criteria. The further requirement is that his or her revelation of facts or evidence goes beyond his or her own contribution to the crime or that it leads to finding a person who participated in a leading role in the commitment of the crime or was active in a leading role in such an association or organisation.

As soon as it is certain that all the prerequisites are met and that punishment, taking into account the weight of the contribution of the information to the investigation or investigation

$\begin{array}{ll}44 & \text { Ibid. } \\ 45 & \text { Strafprozeßordnung, https://www.jusline.at/gesetz/stpo. Accessed } 6 \text { December } 2020 .\end{array}$

46 Böckemühl and Kier oppose the legal regulation of plea bargaining. They argue that pressure on the defendant may not only be exercised by the state prosecutor and the court but also by his own defence counsel. Therefore, even the best law cannot do much about the fact that a good deal depends on the personal relationship of the defence counsel with the state prosecutor and the court. Böckemühl, J., Kier, R., Verständigungen in Strafverfahren - Ein Plädoyer gegen die Kodifizierung einer "StPO light" in Österreich, in: Österreichisches AnwBl 2010, p. 402, cited from: Ehrbar, op. cit. note 42, p. 2.

47 The new Article 209a (as well as the new 209b StPO on crown witnesses in proceedings regarding cartel regulation in competition law) came into force on 1 January 2011 and was initially limited to apply only until 31 December 2016 . The reason for such a limitation was awareness that the crown witness is not completely in line with traditional principles of Austrian criminal and criminal procedure law, especially the principle of the search for substantive truth. After that initial five-year trial-period, 209a StPO was remodelled and its application was extended for another five years until 31 December 2021. One of the main changes in the remodelled Article 209a is that the principle of opportunity has been abandoned and the court is now more involved. Further, only perpetrators who have committed serious offences can now become collaborators of justice, which is a solution of questionable quality. For an overview of the additional changes, see: Prunner, M., "Gibst du mir, dann geb ich dir", Öffentliche Sicherheit, No. 7-8, 2017, pp. 80-81. 
in relation to the type and extent of his or her contribution to the crime, does not appear necessary in order to prevent him or her from committing criminal acts, the public prosecutor's office must instruct the accused to continue to cooperate in the investigation, and the diversion proceedings according to the provisions of Articles 200 to 203 and 205 to 209 StPO are applied. This means that the Austrian crown witness regulation does provide for full impunity for the crown witness, and the criminal procedure against the crown witness can be terminated without a formal guilty verdict in criminal proceedings. According to the Articles regulating diversion proceedings (199, 200 to 203 and 205 to 209 StPO), measures such as the payment of a lump sum or community service are usually imposed on the crown witness. After the services have been provided, the public prosecutor's office must discontinue the preliminary investigation subject to subsequent prosecution. ${ }^{48}$ If the obligation to cooperate in the investigation has been violated or the documents and information provided were incorrect, or if they failed to make a significant contribution or were only provided to disguise the perpetrator's own leading activity in the appointment, association or organisation mentioned, prosecution can be resumed.

From the development of the crown witness regulation in Austrian law, especially the time limitation of its application, but also the partial change of its important features in 2016, it is clear that insistence on respecting the principle of ascertaining the material truth sets huge obstacles for the legislator when regulating some form of collaboration of suspects with justice.

\section{ANALYSIS OF SPECIFIC ASPECTS OF THE CROWN WITNESS AND WITNESS IMMUNITY IN CROATIAN LAW}

\subsection{THE OBJECTIVES OF THESE CONSENSUAL FORMS AND THE PRINCIPLE OF PROPORTIONALITY}

As mentioned in the introduction, in Croatian law there are two consensual forms designed particularly to detect and prove other serious crimes and perpetrators: granting the status of crown witness and witness immunity (or partial witness immunity ${ }^{49}$ ). Both of these procedures are based on the principle of opportunity, which is applied only exceptionally, in cases explicitly prescribed by law, since the dominant principle in Croatian criminal procedural law is the principle of legality or mandatory prosecution which obliges the state attorney to initiate criminal proceedings in the case of reasonable suspicion that a criminal offence prosecuted ex officio has been committed and there are no legal obstacles for the criminal prosecution of that person (Article 2(3) of the Criminal Procedure $\mathrm{Act}^{50}(\mathrm{CPA})$ ). On the other hand, application of the principle of opportunity implies that persons who are granted the status of crown witness or witness immunity will not be convicted as the state attorney will desist from criminal prosecution.

48 Article 209a (3) and (4) of the Austrian StPO.

49 Pavišić, B., Komentar Zakona o kaznenom postupku, Templar-book Šmrika, 2015, p. 373.

50 Zakon o kaznenom postupku, Official Gazette 152/08, 76/09, 80/11, 121/11, 91/12, 143/12, 56/13, 145/13, 152/14, 70/17, 126/19, 126/19. 


\subsubsection{Crown witness}

The "crown witness" or "repentant witness" who agrees to collaborate with the prosecuting authorities and in return be released from prosecution was first introduced in the Criminal Procedure Act of $1997^{51}$ (Article 176). The basic characteristic of the first legislative solution was the distinct legal under-regulation ${ }^{52}$ and the absence of any form of judicial control. The principle of proportionality was only expressed generally - the status could be granted by the State Attorney General to a person against whom a crime report had been filed or who was under criminal prosecution, and who had become a member of a criminal organisation if, "in proportion to the gravity of the offences committed and the importance of that person's testimony", it was "important for the detection of criminal offences and members of a criminal organization". Yet the specific goal of this consensual form was clearly defined: to obtain testimony that was important for the detection of criminal offences and members of a criminal organisation.

The granting of crown witness status was soon regulated in detail in the Act on the Office for the Suppression of Corruption and Organised Crime (AOSCOC) ${ }^{53}$ which entered into force in 2001. In the regulation which is now in force, the AOSCOC of $2009^{54}$, the goals of this consensual form have remained essentially the same, while the principle of proportionality has been put in concrete form through the precise substantive conditions for granting the status of crown witness (Article 36(1) AOSCOC). Therefore, the holder of the status may only be a person against whom the crime report has been filed or against whom criminal proceedings are being conducted for a criminal offence under the jurisdiction of the Office for the Suppression of Corruption and Organised Crime (the Office) and committed within a criminal organisation or criminal association, but only if there are circumstances on the basis of which, according to the Criminal Code, that person can be released from punishment, or if there are mitigating circumstances on the basis of which his or her sentence can be mitigated. According to the jurisprudence of the Supreme Court of the Republic of Croatia (the Supreme Court), even if this condition was met at the time the status of a crown witness was granted, but the court later found that the offence was committed within a group and not within a criminal organisation as required by law, it will not affect the validity and legality of the examination of this witness. ${ }^{55}$

In addition, the status of crown witness cannot be obtained by a person who has committed one of the serious crimes listed in the catalogue of Article 39 AOSCOC, such as murder, aggravated murder, rape, terrorism, serious sexual abuse or exploitation of a child, etc., or if he or she was the organiser of a criminal organisation or association. Therefore, according to the jurisprudence of the Supreme Court, the fact that statutory elements of the crime of attempted murder are realised by the defendant is clearly an obstacle to seeking and granting

51 Zakon o kaznenom postupku, Official Gazette 110/97, 27/98, 58/99, 112/99, 58/02, 143/02, (62/03), 178/04, 115/06.

52 See Novosel, D., Posebnosti Zakona o Uredu za suzbijanje korupcije i organiziranog kriminaliteta, Hrvatski ljetopis za kazneno pravo i praksu, Vol. 8, No. 2, 2001, p. 66.

\footnotetext{
Zakon o Uredu za suzbijanje korupcije i organiziranog kriminaliteta, Official Gazette 76/09, 116/10, 145/10, 57/11, 136/12, 148/13, 70/17.

VSRH, III Kž 5/12-12 of 14 and 15 January 2013. Also VSRH, I Kž-Us 22/11-11 of 8 February 2012.
} 
the status of crown witness. ${ }^{56}$ Still, in such a case, if it turns out that a person interrogated as a crown witness did commit such an offence, his or her testimony will not be illegal evidence. ${ }^{57}$ However, the Supreme Court added that, in such a case, the credibility of that testimony, both separately and in relation to other evidence, "should be assessed with special care" by the court. ${ }^{58}$

The final condition which puts in concrete form the principle of proportionality in the regulation of the crown witness is that the testimony of a person granted such status must be "proportional to the gravity of the committed criminal offence and the importance of the testimony of that person for detecting and proving criminal offences committed within a criminal organisation or criminal association or their perpetrators, or for detecting and preventing criminal offences of a criminal organisation or criminal association" (Article 36(1) AOSCOC). Hence the principle of proportionality is actually reflected at two levels. On the one hand, the testimony must contribute to the prosecution of the most serious criminal offences of organised crime, in relation to which the interest of criminal prosecution actually justifies giving up the criminal prosecution of the crown witness. On the other hand, there must be important mitigating circumstances in relation to the candidate for the status of crown witness to be granted.

Strict observance of the principle of proportionality ensures that the consensual form of granting the status of crown witness is used only as a last resort, when "there are no other possibilities for the effective suppression of organised crime". ${ }^{59}$ It is especially relevant that the meticulous control of compliance with the principle of proportionality is carried out by the court, which will be analysed infra.

\subsubsection{Witness immunity}

Another consensual form, granting partial witness immunity, was introduced into Croatian criminal procedural law with the new CPA of 2008 and was modelled on the corresponding practice of the American (Common Law) system. ${ }^{60}$ This consensual form, just like the crown witness, served the purpose of obtaining witness testimony. The original legal regulation was, though, thoroughly amended in 2013, after the decision of the Constitutional Court of July 2012 which declared this consensual form unconstitutional, primarily due to non-compliance with the principle of proportionality. ${ }^{61}$ Granting witness immunity was initially intended for the proving of the most serious criminal offences, punishable with imprisonment of ten years or more, but could be granted even to a person who committed a serious criminal offence equal to the one being proven by means of his or her testimony, ${ }^{62}$ and all this without any

56 VSRH, I Kž-23/2015 of 7 June 2016.

57 VSRH, I Kž-23/2015 of 7 June 2016 and VSRH, Kž-rz 15/2018-6 of 8 January 2019.

58 VSRH, Kž-rz 15/2018-6 of 8 January 2019.

59 Krapac, D., Kazneno procesno pravo Prva knjiga: Institucije, Narodne novine, Zagreb, 2020, p. 492.

60 Pavišić, B., op. cit. note 49, p. 373.

61 Constitutional Court of the Republic of Croatia, U-I-448/2009, of 19 July 2012, points $143-146.3$

62 The Supreme Court confirmed that "it does not follow from the wording of Article 286 paragraph 3 CPA/08 that a more serious offence of another person than the one granted partial immunity should be proved in the sense that a harsher punishment is 
judicial control. ${ }^{63}$ The Constitutional Court pointed out that it was necessary to regulate the discretionary powers of the state attorney which were too wide. ${ }^{64}$

The main difference between this consensual form, as currently regulated, and the crown witness lies in the fact that a person being granted witness immunity, at that time, is not a suspect. ${ }^{65}$ In this sense, the state attorney does not offer him or her a waiver of prosecution, but guarantees that, based on the facts he or she states in his or her testimony, which could be self-incriminating or could incriminate a close relative, he or she will not be prosecuted. In other words, witness immunity may be granted if a witness refuses to answer a particular question, so as not to incriminate himself or herself or a close relative (Article 286(2) CPA). Therefore, this type of immunity protects the witness from prosecution in connection with his or her testimony. ${ }^{66}$ The principle of proportionality is given definite form in the provisions that witness immunity may be granted only in relation to a criminal offence which may be punished only by a lesser punishment than that for the offence in respect of which the witness testimony is obtained, and in any case this punishment may not amount to ten years or more. Yet, according to the jurisprudence of the Supreme Court, the fact that the witness testimony was given in accordance with the previous legislation, i.e. before the possibility of granting "partial immunity" was limited to criminal offences punishable by imprisonment for up to ten years, does not affect the legality of that testimony as evidence, notwithstanding the aforementioned decision of the Constitutional Court. ${ }^{67}$ The Supreme Court clarified that the validity of an evidentiary action is assessed according to the regulation in force at the time of its performance. ${ }^{68}$ Yet, if the same logic as that which regards the crown witness should apply (supra 3.1.1), this would mean that the credibility of such testimony, both separately and in relation to other evidence, should be assessed with special care by the court.

In addition, the principle of proportionality implies that the offence, which will be proven by the testimony of that witness, must be a serious criminal offence listed in the catalogue of Article 286(2) CPA. The point is that the interest in prosecuting such serious offences justifies the granting of witness immunity and the waiver of possible prosecution for another criminal offence.

\subsubsection{View from the comparative legal perspective}

Looking from the comparative legal perspective, the Croatian legislator, like the Austrian one and unlike the French, Italian and German legislators, chose to regulate in detail the consensual form of granting the status of crown witness in the Criminal Procedure Act. The prin-

prescribed, but a more serious offence for which imprisonment of ten years or more is prescribed, in terms of its seriousness...". VSRH, I Kž-Us 103/13-4 of 11 December 2013.

63 See Đurđević, Z., Procesna jamstva obrane prema suokrivljeniku kao svjedoku optužbe, Hrvatski ljetopis za kazneno pravo i praksu, Vol. 16, No. 2, 2009, pp. $793-794$.

64 Krapac, op. cit. note 59, p. 108.

65 See Ivičević Karas, op. cit. note 6, p. 415.

66 Pavišić, op. cit. note 49, p. 373.

67 VSRH, I Kž-Us 100/16-4 of 7 September 2016. 
ciple of proportionality is given specific form through several conditions for the application of the function of crown witness. If the repentant witness fulfils his or her obligation, ${ }^{69}$ the state attorney will desist from prosecution, again as in Austrian law. It is, though, important to emphasise that in Croatian law the whole procedure is under strict judicial control.

On the other hand, the procedure of granting witness immunity is unique among the European continental legal systems included in this study, with the exception of the mentioned provision existing in French law based on the principle of opportunity (see supra 2.2.2.). As already pointed out, it was inspired by the American model of statutory immunity. Although regulated in compliance with strict requirements of the principle of proportionality, granting witness immunity still leaves great discretion to the state attorney to decide on whether to desist from criminal prosecution, ${ }^{70}$ which will be discussed infra.

\subsection{STATE ATTORNEY'S DISCRETION VS. JUDICIAL CONTROL}

Applying both consensual forms, that of the crown witness and witness immunity, the state attorney acts in accordance with the principle of opportunity. This means that the state attorney will not prosecute, even when there is reasonable suspicion that a criminal offence that is prosecuted ex officio has been committed and when there are no legal obstacles, if prosecution would not be in the public interest. ${ }^{71}$ In this case, justified public interest would lie in detecting and proving other more serious criminal offences and their perpetrators.

When granting witness immunity, the decision of the state attorney not to prosecute is final. On the other hand, as concerns the crown witness, the state attorney, acting in accordance with the principle of opportunity, may propose to the court the granting of that status, and the court will then decide. So, this consensual procedure can be concluded only on the basis of a court decision rendered after a thorough judicial review of all substantive conditions (see supra 3.1.1.). This means that the court makes the final decision whether a waiver of prosecution, according to the principle of opportunity, in the specific case, really is in the public interest.

The request for granting the status of crown witness, at the proposal of the Director of the Office, is submitted to the court by the State Attorney General (Article 36(2) AOSCOC). The

69 In the process of acquiring the status of crown witness, a person must give a written statement that as a witness in criminal proceedings he or she will testify only the truth and that he or she will not keep silent about any relevant circumstance (Article 38(2) AOSCOC). When the witness fulfils the stated obligation and testifies, the state attorney will give up criminal prosecution (Article $45 \mathrm{AOSCOC}$ ). However, if the witness fails to fulfil the obligation, or if he or she commits a new criminal offence within the jurisdiction of the Office before the final termination of the proceedings, or if within two years of acquiring the status of crown witness he or she becomes a member of a criminal organisation or association, he or she will lose the status of crown witness and the state attorney will continue or initiate criminal proceedings against him or her (Article $46 \mathrm{AOSCOC}$ ).

70 In the process of acquiring witness immunity, the witness gives a written statement that he or she will tell the truth in the criminal proceedings and that he or she will not keep silent about anything he or she knows about the criminal offence he or she is testifying about and about its perpetrator (Article 286(3) CPA). However, if the witness's answer to the question in respect of which he or she has been granted immunity is not complete, is not circumstantial, and is not supported by other evidence, the state attorney shall deny the statement not to prosecute, while the given answer will be excluded from the case file and kept separately (Article 286 (6) CPA). 
request can be submitted until the trial is scheduled. The panel of the competent court will decide on the request on the basis of documents and other written evidence. However, the panel may, if necessary, hold a session and invite the State Attorney General and the person in respect of whom the status of crown witness has been proposed, as well as his or her defence counsel (Article 40(3) AOSCOC). The court will check whether all material conditions for granting the status of crown witness are met, including whether the witness testimony is in the interest of detecting and prosecuting other members of a criminal organisation or association, and the State Attorney General may file an appeal, which will be decided by the Supreme Court (Article 41(3) AOSCOC). A similar procedure can be carried out in relation to a convicted member of a criminal organisation or association, where the final judgment regarding the sentence will be abolished or reduced in exchange for a witness statement, or the State Attorney General will file a motion for parole (Article 37 AOSCOC).$^{72}$

On the other hand, the granting of witness immunity is left entirely to the discretion of the state attorney. The state attorney is bound by the prescribed material conditions, but the manner in which he or she assesses proportionality is not subject to any judicial review. Witness immunity is granted by a written statement of the state attorney, which must be certified by a superior state attorney.

The issue of judicial control is one of the key issues in the application of both of these consensual forms. But while, on the one hand, thorough judicial control is ensured in the process of granting crown witness status, it is entirely absent in the procedure of granting witness immunity. This might seem contradictory at first sight if we know that both consensual forms are based on the application of the principle of opportunity, which implies a waiver of prosecution in exchange for witness testimony, and consequently the absence of a conviction. Yet, there is an important difference between the status of crown witness and witness immunity. The status of crown witness may be granted to a person against whom a crime report has been filed or who is under criminal prosecution so the state attorney must make a decision on that prosecution. On the other hand, in relation to a person to whom witness immunity is offered, the state attorney does not yet have incriminating evidence, so the state attorney cannot initiate criminal prosecution at that stage. ${ }^{73}$ Moreover, the incriminating evidence will probably be presented only after the conclusion of the agreement, knowing that any witness has the right to refuse to answer a specific question if the answer would incriminate the witness or his or her close relative. This means that the state attorney, without the testimony, would not be able to initiate prosecution and a person who has been granted witness immunity will never have the status of suspect or defendant unless other evidence arises to support reasonable suspicion.

Consequently, it is clear that witness immunity cannot be offered to a person who already has the status of suspect, i.e. if there are grounds for suspicion that he or she has committed a criminal offence and the police or the state attorney are taking action to clarify that suspicion (in terms of Article 202(2)1 CPA defining the notion of "suspect"). In this case, the state attorney will be bound by the principle of legality and will have to prosecute that person. In other

72 See Ivičević Karas, op. cit note 6, p. 414.

73 Ivičević Karas, E., Prilog raspravi o problemu miješanja procesnih uloga u kaznenom postupku, in: Kazneno pravo: sinergija teorije i prakse, Liber amicorum Petar Novoselec (eds. Turković, K., Munivrana Vajda, M., Dragičević Prtenjača, M.), Pravni fakultet Sveučilišta u Zagrebu, Zagreb, 2019, pp. 234 - 235. 
words, the state attorney will not be able to grant a suspect witness immunity, either formally or informally. If the state attorney did so, the court should react as soon as the issue is raised in the proceedings.

Croatian criminal procedural law prescribes the cognitive criterion as a basis for distinguishing between the procedural roles of a suspect and a (presumptive) witness (in accordance with Article 202(2)1 CPA). ${ }^{74}$ This means that when, in relation to a person with whom, during an informative conversation with the police, grounds appear for suspicion that he or she has committed a criminal offence, or that he or she has participated in the commission of a criminal offence, the informative conversation cannot continue. This person may be questioned by the police only as a suspect with a prior instruction on rights. ${ }^{75}$ The same logic applies to a witness who is examined by a state attorney and who begins to incriminate himself or herself during the examination. ${ }^{76}$ According to the law, such a person may not be further examined as a witness, unless, under terms prescribed by law, he or she is granted the status of crown witness. Such a person cannot obtain witness immunity either, since, by incriminating himself or herself, he or she has acquired the status of suspect in accordance with the mentioned Article 202(2)1 CPA.

So, if the state attorney manipulates the procedural roles when granting witness immunity, the court may not order the state attorney to prosecute, but may question the legality of such testimony. The Constitutional Court, in the earlier-mentioned decision, warned of the inadmissibility of examining the defendant as a witness, pointing out: "if there is any evidence that a person in the status of a witness in the proceedings against another person within the meaning of Article 286 of the CPA has committed a criminal offence, there is automatically a legal prohibition on the application of that article of the CPA. If such evidence were to be applied in such a case, it would be unlawful evidence within the meaning of Article $10 \S 2$ (3) of the $\mathrm{CPA}^{\prime \prime}{ }^{77}$ i.e. ex lege unlawful evidence which must be excluded from the case file. ${ }^{78}$ The same reasoning should apply in essentially the same situation - if the state attorney did not formally grant witness immunity, but examined as a witness a person in relation to whom there is suspicion that he or she committed a criminal offence in relation to which criminal proceedings are being conducted, or participated in committing the criminal offence. In virtue of the Constitutional Court's attitude, such a statement should also be treated as unlawful evidence. But this attitude has not been accepted in judicial practice. In one case decided by the Supreme Court, the defence requested the exclusion of records of the examination of witnesses as illegal evidence, because, in those statements, the witnesses incriminated themselves, but the examination was not interrupted, nor were those persons examined as suspects, nor were they assigned partial witness immunity in virtue of Article 286 CPA. ${ }^{79}$ However, the Supreme Court only briefly explained that the procedural status of these witnesses did not change, i.e. their

\footnotetext{
$74 \quad$ Ibid., p. 232.

75 Ibid, pp. 232- 233.

76 See Ivičević Karas, E., Burić, Z., Bonačić, M., Neka pitanja usklađenosti hrvatskoga kaznenog procesnog prava s direktivama o pravima obrane - analiza sudske prakse, Hrvatski ljetopis za kaznene znanosti i praksu, Vol. 27, No. 2, 2020, pp. 556 - 558.

77 Constitutional Court of the Republic of Croatia, U-I-448/2009 of 19 July 2012, point 146. See Ivičević Karas, op. cit. note 73, p. 235. 
procedural role at a later stage of the proceedings since they remained witnesses, so there is no question of the illegality ex judicio of this evidence. ${ }^{80}$ The Supreme Court obviously failed to comment on whether the state attorney informally, outside the prescribed procedure, granted procedural immunity to witnesses in this case, which, according to the Constitutional Court's interpretation, would certainly lead to the illegality of such evidence ex lege.

In conclusion, as explained above, Croatian criminal procedure is founded on the principle of legality, or mandatory prosecution. The state attorney may deviate from the principle of legality only in cases strictly prescribed by law, when applying the principle of opportunity. But the principle of opportunity can never be applied arbitrarily, and this is an extremely important issue that must be subject to strict judicial control. Looking from the comparative legal perspective, at least from the standpoint of those continental European legal systems that are founded on the principle of legality or mandatory prosecution, the court ultimately decides on any measure of reward, whether this is mitigation or remission of punishment in Germany and Italy. Even in France, where the principle of opportunity dominates, the court decides on measures of reward for collaborators of justice. Only in Austrian law is the decision on granting the status of crown witness left to the state attorney.

\subsection{PROCEDURAL AND DEFENCE RIGHTS}

The procedural position of a suspect or defendant who aspires to become a "repentant witness" and then a crown witness differs significantly from the position of a person who could acquire witness immunity. The former is in a position to possibly choose between being prosecuted and testifying in exchange for the waiving of prosecution, while the latter chooses between refusing to answer a particular question, which would be self-incriminating, and giving an answer with the prior guarantee of witness immunity. It is quite clear that the position of the latter is much more favourable, so it is surprising that the legislator prescribed the mandatory assistance of a lawyer only when giving a statement in the procedure of granting witness immunity (Article 286(3) CPA), but not in the procedure of granting the status of crown witness. The law states that a suspect or a defendant may be summoned to a session of the panel that decides on the request for granting the status of crown witness, as may a defence counsel "if any" (Article 40 (3) AOSCOC). Only if proceedings are conducted in relation to a convicted person is the presence of a defence counsel mandatory when giving a statement (Article 37 (2) AOSCOC). The sensitivity of the legal positions of both would justify mandatory assistance by a defence counsel. ${ }^{81}$

A question that has arisen in court practice, in the context of defence rights, refers to whether the defendant has the right to participate and influence the outcome of the procedure for granting the status of crown witness. The Supreme Court has repeatedly pointed out that this is a procedure that takes place between the State Attorney General, the potential crown witness, and the court, and that the accused has no possibility to participate in or influence

\footnotetext{
80 Ibid.

81 See Ivičević Karas, op. cit. note 6, p. 428.
} 
that procedure. ${ }^{82}$ The exclusion of the public during the examination of the crown witness at the hearing is another issue that has been disputed in practice, but the Supreme Court has repeatedly pointed out that the exclusion of the public is ex lege mandatory, and not an issue left to the discretion of the court. ${ }^{83}$

\subsection{VICTIMS’ RIGHTS}

As far as victims' rights are concerned, they are not a key issue in either of these two consensual forms. Thus, victims are not at all involved in the negotiation process between the state attorney and a potential crown witness, or a person with potential witness immunity. However, in the procedure of granting the status of crown witness, the law gives the court the opportunity (but not the obligation) to take care of the interests of potential victims, i.e. injured parties. So the panel of the competent court may make its decision on granting the status of crown witness conditional on the possibility for the Republic of Croatia to compensate persons who have been harmed by a repentant witness for criminal offences committed as a member of a criminal organisation or association (Article 40(4) AOSCOC). This means that the state, within the framework of the agreement, also takes over claims that could be the subject of a civil claim in criminal proceedings against a repentant witness, if conducted. On the other hand, in the procedure of granting witness immunity, the law does not prescribe such a possibility.

From a comparative legal perspective, victims' rights are not in the focus of the legislator's interest when it comes to consensual forms geared to obtaining witness testimony. Yet, having in mind the tendencies, especially in European law, to reinforce the possibilities of victims to actively participate in criminal procedures and to represent their own legitimate interests, ${ }^{84}$ it is justified to question the adequacy of the victim's role and the protection of the victim's interests in consensual forms intended for collaborators of justice stricto sensu.

\section{CONCLUSION}

In contemporary legal systems, collaborators of justice, as (potential) suspects and defendants willing to cooperate with authorities primarily by providing their testimonies before the court, are often an indispensable "tool" for the prosecution of the most serious criminal offences, including terrorism, corruption and organised crime. This comparative study has shown that measures of reward, envisaged for those ready to collaborate with the authorities in detecting and prosecuting the most serious criminal offences, may be of a substantive or

82 VSRH, III Kž 5/12-12 of 14 and 15 January 2013; VSRH, I Kž-Us 92/10-6 of 30 June 2010; VSRH, I Kž 1113/07-3 of 28 November 2007.

83 VSRH, I Kž-Us 36/11-11 of 28 February 2012; VSRH, I Kž-Us 66/10-3 of 4 May 2010; VSRH, I Kž 671/08-5 of 23 July 2008, VSRH, I Kž 1113/07-3 of 28 November 2007. 
procedural nature, and may be regulated by national criminal codes, codes of criminal procedures, or/and special legislation. Measures of reward provided within particular consensual procedural forms may be founded on the principle of legality or mandatory prosecution which implies the conviction of the collaborator of justice, but with the imposition of a more lenient punishment, or may be based on the principle of opportunity which implies not undertaking or waiving public prosecution, and consequently the absence of conviction. Solutions in comparative law are many and varied, but what they all have in common is that they open up many fundamental criminal procedural law issues as discussed in this paper.

As concerns the Croatian regulation of the legal position of the crown witness and a person granted witness immunity, the study has shown that relatively clear normative regulation still opens up some questions in judicial practice. Strong judicial control in the process of granting the status of crown witness and the clearly prescribed principle of proportionality have probably contributed to the fact that the Supreme Court has so far not pointed to any major illegalities in the procedure of granting that status, nor later in the use of the testimony of a crown witness as evidence in criminal proceedings. Yet, the lack of judicial control when granting witness immunity can and should be compensated for later in the procedure if the question of the legality of granting such a status, whether formally or informally, is raised before the court.

\section{REFERENCES}

1. Beernaert, M.-A., De l'irrésistible ascension des « repentis » et « collaborateurs de justice » dans le système pénal, Déviance et Société, Vol. 27, No. 1, 2003, pp. 77 - 91.

2. Beernaert, M-A., «Repentis » ou « collaborateurs de justice » : quelle légitimité dans le système pénal ? » Droit et société, No. 55, 2003/3, pp. 693 - 711.

3. Bouloc, B., Procédure pénale, Dalloz, Paris, 2012.

4. Crijns, J.H., Dubelaar, M.J.;, Pitcher, K.M., Collaboration with Justice in the Netherlands, Germany, Italy and Canada, Leiden University, 2017.

5. Damaška, M., Dokazno pravo u kaznenom postupku: oris novih tendencija, Pravni fakultet u Zagrebu, 2001.

6. Dervan, L. E., Arriving at a System of Pleas: The History and State of Plea Bargaining, in: A System of Pleas (eds. Edkins, V. A., Redlich, A. D.), Oxford University Press, 2019, pp. 11 - 23.

7. Đurđević, Z., Procesna jamstva obrane prema suokrivljeniku kao svjedoku optužbe, Hrvatski ljetopis za kazneno pravo i praksu, Vol. 16, No. 2, 2009, pp. 783 - 808.

8. Fyfe, N., Sheptycki, J., International Trends in the Facilitation of Witness Co-operation in Organized Crime Cases, European Journal of Criminology, Vol. 3, No. 3, 2006, pp. 319 - 355.

9. Hamdan, S., Absprachen im französischen Strafverfahren?, Nomos, 2018.

10. Ivičević Karas, E., Burić, Z., Bonačić, M., Neka pitanja usklađenosti hrvatskoga kaznenog procesnog prava s direktivama o pravima obrane - analiza sudske prakse, Hrvatski ljetopis za kaznene znanosti i praksu, Vol. 27, No. 2, 2020, pp. $543-569$.

11. Ivičević Karas, E., Consensual Justice in Croatian Criminal Procedural Law: The Need for a Systematic Approach, in „EU 2020 - Lessons from the Past and Solutions for the Future, EU and Comparative Law Issues and Challenges Series (ECLIC) - ISSUE 4, University of Josip Juraj Strossmayer Faculty of Law, Osijek, 2020, pp. $405-432$. 
12. Ivičević Karas, E., Prilog raspravi o problemu miješanja procesnih uloga u kaznenom postupku, in: Kazneno pravo: sinergija teorije i prakse, Liber amicorum Petar Novoselec (eds. Turković, K., Munivrana Vajda, M., Dragičević Prtenjača, M.), Pravni fakultet Sveučilišta u Zagrebu, Zagreb, 2019, pp. 229 $-243$.

13. Krapac, D., Kazneno procesno pravo Prva knjiga: Institucije, Narodne novine, Zagreb, 2020.

14. Novosel, D., Posebnosti Zakona o Uredu za suzbijanje korupcije i organiziranog kriminaliteta, Hrvatski ljetopis za kazneno pravo i praksu, Vol. 8, No. 2, 2001, pp. 41 - 83.

15. Pajčić, M., Ugroženi svjedoci u kaznenom postupku, Hrvatsko udruženje za kaznene znanosti i praksu, Ministarstvo unutarnjih poslova RH, Zagreb, 2006.

16. Pavišić, B., Komentar Zakona o kaznenom postupku, Templar-book Šmrika, 2015.

17. Prunner, M., "Gibst du mir, dann geb ich dir“, Öffentliche Sicherheit, No. 7-8, 2017, pp. 80 - 81.

18. Tak, P. J. P., Deals with Criminals: Supergrasses, Crown Witnesses and Pentiti, European Journal of Crime, Criminal Law and Criminal Justice, Vol. 5, No. 1, 1997, pp. 2 - 26.

19. Turner, J. I., Plea Bargaining Across Borders, Wolters Kluwer, 2009.

\section{LIST OF REGULATIONS AND ACTS}

1. Code de procédure pénale, Version en vigueur au 08 décembre 2020, https://www.legifrance.gouv. fr/codes/texte_lc/LEGITEXT000006071154/. Accessed 6 December 2020.

2. Code pénal, Version en vigueur au 08 décembre 2020, https://www.legifrance.gouv.fr/codes/texte_ lc/LEGITEXT000006070719/. Accessed 8 December 2020.

3. Decreto - legge 15 gennaio 1991, n.8, convertito, con modificazioni, dalla legge 15 marzo 1991, n.82, come modificata dalla legge 13 febbraio 2001 n. 45, https://www1.interno.gov.it/mininterno/ export/sites/default/it/assets/files/23/0479_Decreto-Legge_15_gennaio_1991x_convertito_nella_L._15_marzo_1991x_n._82.pdf. Accessed 17 December 2020.

4. Kazneni zakon, Official Gazette 125/11, 144/12, 56/15, 61/15, 101/17, 118/18, 126/19.

5. Legge sull'ordinamento penitenziario, L. 26 luglio 1975, n. 354, il testo coordinato della Legge sull'ordinamento penitenziario aggiornata, da ultimo, dal D.L. 10 maggio 2020, n. 29. Norme sull'ordinamento penitenziario e sulla esecuzione delle misure privative e limitative della libertà, https://www.altalex.com/documents/codici-altalex/2018/11/26/legge-sull-ordinamento-penitenziario\#titolo1. Accessed 17 December 2020.

6. Loi Perben II (Loi n²004-204 du 9 mars 2004 - art. 12 () JORF 10 mars 2004), https://www.legifrance.gouv.fr/jorf/id/JORFTEXT000000249995/. Accessed 7 December 2020.

7. Strafgesetzbuch, https://www.gesetze-im-internet.de/stgb/BJNR001270871.html. Accessed 6 December 2020.

8. Strafprozeßordnung, https://www.gesetze-im-internet.de/stpo/StPO.pdf. Accessed 6 December 2020.

9. Strafprozeßordnung, https://www.jusline.at/gesetz/stpo. Accessed 6 December 2020.

10. Zakon o kaznenom postupku, Official Gazette 110/97, 27/98, 58/99, 112/99, 58/02, 143/02, (62/03), 178/04, 115/06.

11. Zakon o kaznenom postupku, Official Gazette 152/08, 76/09, 80/11, 121/11, 91/12, 143/12, 56/13, 145/13, 152/14, 70/17, 126/19, 126/19. 
12. Zakon o Uredu za suzbijanje korupcije i organiziranog kriminaliteta, Official Gazette 88/01, 12/02, 33/05, 76/07.

13. Zakon o Uredu za suzbijanje korupcije i organiziranog kriminaliteta, Official Gazette 76/09, 116/10, 145/10, 57/11, 136/12, 148/13, 70/17.

\section{DECISIONS OF THE SUPREME COURT OF THE REPUBLIC OF CROATIA}

1. VSRH, I Kž 1113/07-3 of 28 November 2007.

2. VSRH, I Kž 671/08-5 of 23 July 2008.

3. VSRH, I Kž-Us 66/10-3 of 4 May 2010.

4. VSRH, I Kž-Us 92/10-6 of 30 June 2010.

5. VSRH, I Kž-Us 22/11-11 of 8 February 2012.

6. VSRH, I Kž-Us 36/11-11 of 28 February 2012.

7. VSRH, III Kž 5/12-12 of 14 and 15 January 2013.

8. VSRH, I Kž-Us 103/13-4 of 11 December 2013.

9. VSRH, I Kž-23/2015 of 7 June 2016.

10. VSRH, I Kž-Us 100/16-4 of 7 September 2016.

11. VSRH, I Kž-Us 88/2018-4 of 22 November 2018.

12. VSRH, Kž-rz 15/2018-6 of 8 January 2019.

\section{WEBSITE REFERENCES}

1. Coppola, S., Chi è il collaboratore di giustizia, 8 Gennaio 2018, https://www.laleggepertutti. it/184662_chi-e-il-collaboratore-di-giustizia. Accessed 17 December 2020.

2. Ehrbar, K., Plea Bargaining, at 2018. Congress of European Criminal Bar Association, available at: http://www.ecba.org/extdocserv/conferences/oslo2018/PleaBargainingEhrbar.pdf. Accessed 6 December 2020.

3. Scarpino, F., Il fenomeno della collaborazione con lo stato, La figura del "collaboratore di giustizia ", 7 Marzo 2016, https://www.filodiritto.com/il-fenomeno-della-collaborazione-con-lo-stato-0. Accessed 17 December 2020. 


\section{SURADNICI PRAVOSUĐA: POREDBENOPRAVNA RJEŠENJA I HRVATSKO KAZNENO PROCESNO PRAVO}

\section{Sažetak}

Ovaj rad analizira procesni položaj "suradnika pravosuđa” - (potencijalnih) osumnjičenika ili okrivljenika koji odluče surađivati s vlastima doprinoseći otkrivanju i kaznenom progonu drugih teških kaznenih djela i počinitelja, prvenstveno svjedočenjem pred sudom. Cilj istraživanja je pružiti pregled konsenzualnih oblika i mjera nagrađivanja suradnika pravosuđa u poredbenom pravu, a zatim analizirati pravni položaj krunskog svjedoka i osobe kojoj je dodijeljen imunitet svjedoka kao "suradnika pravosuđa" u hrvatskom kaznenom procesnom pravu. Istraživanje je provedeno kroz poredbenopravnu perspektivu i s obzirom na određena pitanja koja su dosad bila problematizirana u znanstvenoj i stručnoj literaturi te domaćoj sudskoj praksi, a koja uključuju: specifični cilj ovih konsenzualnih oblika i primjenu načela razmjernosti, diskrecijske ovlasti državnog odvjetnika i sudsku kontrolu, procesna prava i prava obrane te naposljetku prava žrtava. Posebna pozornost posvećena je analizi prakse Vrhovnog suda Republike Hrvatske i njegovih pravnih standarda, napose glede određenih pitanja zakonitosti ispitivanja krunskog svjedoka, kao i zakonitosti ispitivanja osobe kojoj je dodijeljen imunitet svjedoka.

Ključne riječi: $\quad$ suradnici pravosuđa, krunski svjedok, imunitet svjedoka, sudska kontrola, mjere nagradivanja

\section{(c) (1) (\$)}

\footnotetext{
Dr. sc. Elizabeta Ivičević Karas, redovita profesorica Pravnog fakulteta Sveučilišta u Zagrebu, Trg Republike Hrvatske 14, 10000 Zagreb. E-adresa: elizabeta.ivicevic@pravo.hr. ORCID: https://orcid.org/0000-0001-5279-3709.

** Dr. sc. Zoran Burić, docent Pravnog fakulteta Sveučilišta u Zagrebu, Trg Republike Hrvatske 14, 10000 Zagreb. E-adresa: zoran. buric@pravo.hr. ORCID: https://orcid.org/0000-0001-5353-8478.

** Dr. sc. Matko Pajčić, docent Pravnog fakulteta Sveučilišta u Splitu, Domovinskog rata 8, 21000 Split. E-adresa: mpajcic@pravst. hr. ORCID: https://orcid.org/0000-0003-0657-1245.
} 